[Radiocarbon, Vol 22, No. 3, 1980, P 885-891]

\title{
CARBON ISOTOPE MEASUREMENT AS AN INDEX OF SOIL DEVELOPMENT
}

\section{$S$ J LADYMAN and D D HARKNESS}

NERC Radiocarbon Laboratory, Scottish Universities Research and Reactor Centre, East Kilbride, Scotland

ABSTRACT. ${ }^{14} \mathrm{C}$ and ${ }^{13} \mathrm{C}$ enrichment values are reported for a series of surface soil profiles which represent the progressive transition from mor to mull humus induced by birch (Betula pendula) colonization.

Variations in $\Delta$ and $\delta^{13} \mathrm{C}$, which range between 85 to $154 \%$ modern and -28.1 to $-25.3 \%$ (PDB), respectively, reflect changes in the rate and mode of organic decomposition. The most marked alterations in soil character occur over the first few decades following the introduction of birch, with clear isotopic evidence for the deeper penetration and accelerated mineralization of organic material.

\section{INTRODUCTION}

A continuing research interest at the NERC Radiocarbon Laboratory is with the determination of variations in the natural isotopic abundances in soil organic matter. The primary objective is to assess the potential value of such measurements as a supplement to those non-isotopic techniques already established for the study of the biologically active surface layers of soils.

We report and discuss here the progress achieved for a specific application of carbon isotope analyses within the overall research program viz, an investigation of the progressive changes in soil structure induced by the tree species, Betula pendula. The reputation of birch ( $B$ pendula) as having the capability to induce marked changes in soil character is widely cited in general treatises on forest management. In particular, Dimbleby $(1951 ; 1952 ; 1953)$ has discussed the effectiveness of birch in reversing the podsolization process in moorland surface soils and with the eventual production of brown forest soil conditions.

A natural ecological succession from heather moor to well-established birch stand has been described by Miles (1977; pers commun) on the basis of conventional soil analyses. The availability of these data provided an ideal opportunity for direct isotopic comparison.

\section{Study sites}

The soil succession originally identified and studied by $\mathrm{J}$ Miles occurs on Tulchan Estate in the Spey Valley, Scotland $\left(57^{\circ} 25^{\prime} \mathrm{N}, 3^{\circ} 25^{\prime} \mathrm{W}\right)$.

At various times past, areas of established heather moor had burned back allowing the podsolized parent soil (mor humus) under the heath to become naturally colonized, first by grass (Deschampsia flexuosa) and, subsequently, by birch. Within a $2 \times 10^{5} \mathrm{~m}^{2}$ area, discrete sites were identified as representing the parent heather moorland and, on the basis of tree development, 20, 28, 40, and 92-year-old stands of birch.

Preliminary inspection showed that considerable alteration of the soil structure had occurred after 28 years of birch growth and with little remaining evidence of podsolization at the 40 -year-old birch site. The trees in the oldest (92-year) birch stand showed clear evidence of senility and die-back, and bracken (Pteridium typica) was beginning to colonize 
this site. Soil under the 20-year-old birch was much shallower than at the other sites and its suitability for inter-site comparison was suspect from the outset.

\section{EXPERIMENTAL METHODS AND RESULTS}

Sampling. Samples were collected during autumn 1976. Whole soil was taken from a vertical face of freshly dug pits in progressive increments of 5,10 , or $15 \mathrm{~cm}$ depth. For each soil profile, the entire A horizon was sampled and, with the exception of the 20-year-old birch site, the upper levels of the B horizon (fig 1). The depth interval required for individual samples was decided in the field after visual assessment of the distribution of organic material in the soil matrix. All dead but unhumified organic matter overlying the mineral surface was taken to represent 'litter'.

For this study, only one litter/soil profile was sampled per site. Harkness and others ( $m$ s in preparation) had already evidenced an acceptable degree of constancy for ${ }^{14} \mathrm{C}$ enrichment measured as a function of soil depth over several randomly spaced sites within a specific woodland.

Determination of total carbon content. The distribution of carbon in each soil profile is expressed as the mean surface density $\left(\mathrm{g} \mathrm{cm}^{-2}\right)$ for specified depth intervals (fig l). Percent loss on ignition values (measured on our behalf by the Institute of Terrestrial Ecology, Merlewood) were

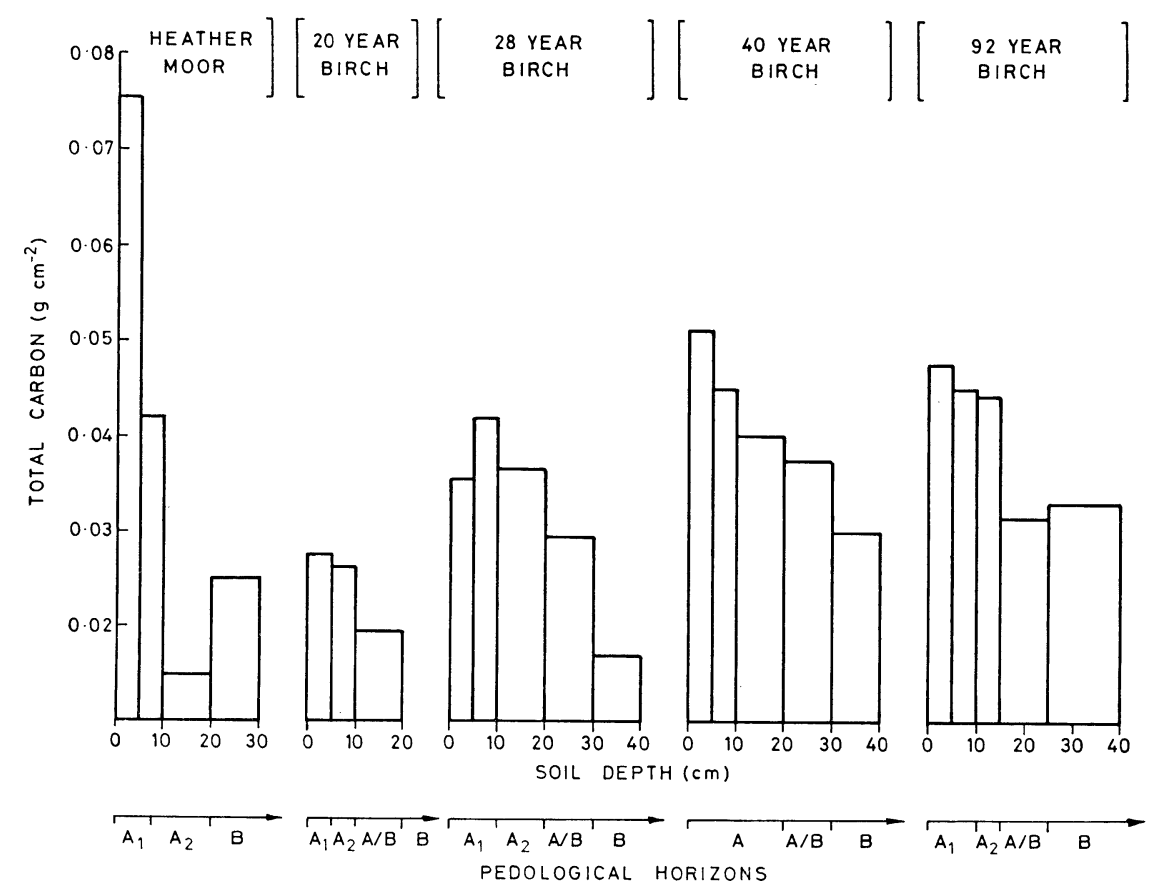

Fig 1. Estimated distribution of total soil carbon as a function of sampled depth increments and pedological horizons. 
used to estimate soil bulk density. The weight percent carbon in dried soils was calculated routinely in the preparation of $\mathrm{CO}_{2}$ for ${ }^{13} \mathrm{C} /{ }^{12} \mathrm{C}$ measurement (see below).

${ }^{14} \mathrm{C} /{ }^{12} \mathrm{C}$ measurement. Soil samples were first hand-sorted to remove unhumified organic material and then suspended in an acid/antioxidant solution. Any remaining unhumified material was removed by flotation and the suspension then evaporated to dryness.

Radiometric analysis was by the liquid scintillation method as applied routinely at the NERC Radiocarbon Laboratory (Harkness and Wilson, 1972). Calculated ${ }^{14} \mathrm{C}$ enrichment values (fig 2) include standard normalization of the measured sample activities (rel to -25\% PDB) in compensation for natural and any laboratory induced fractionation viz,

$$
{ }^{14} \mathrm{C}(\% \text { modern })=\left[1+\frac{\mathrm{D}^{14} \mathrm{C}}{1000}\right] 100
$$

Analytical precision for the reported data is within \pm 2 percent modern at the $2 \sigma$ confidence level.

${ }^{13} \mathrm{C} /{ }^{12} \mathrm{C}$ measurement. Soil samples were air-dried and then ground to a fine powder in a ceramic ball-mill. The total carbon in accurately weighed aliquots of each soil was recovered by its quantitative oxidation to $\mathrm{CO}_{2}$ in a quartz semi-micro combustion rig. The gas was dried and

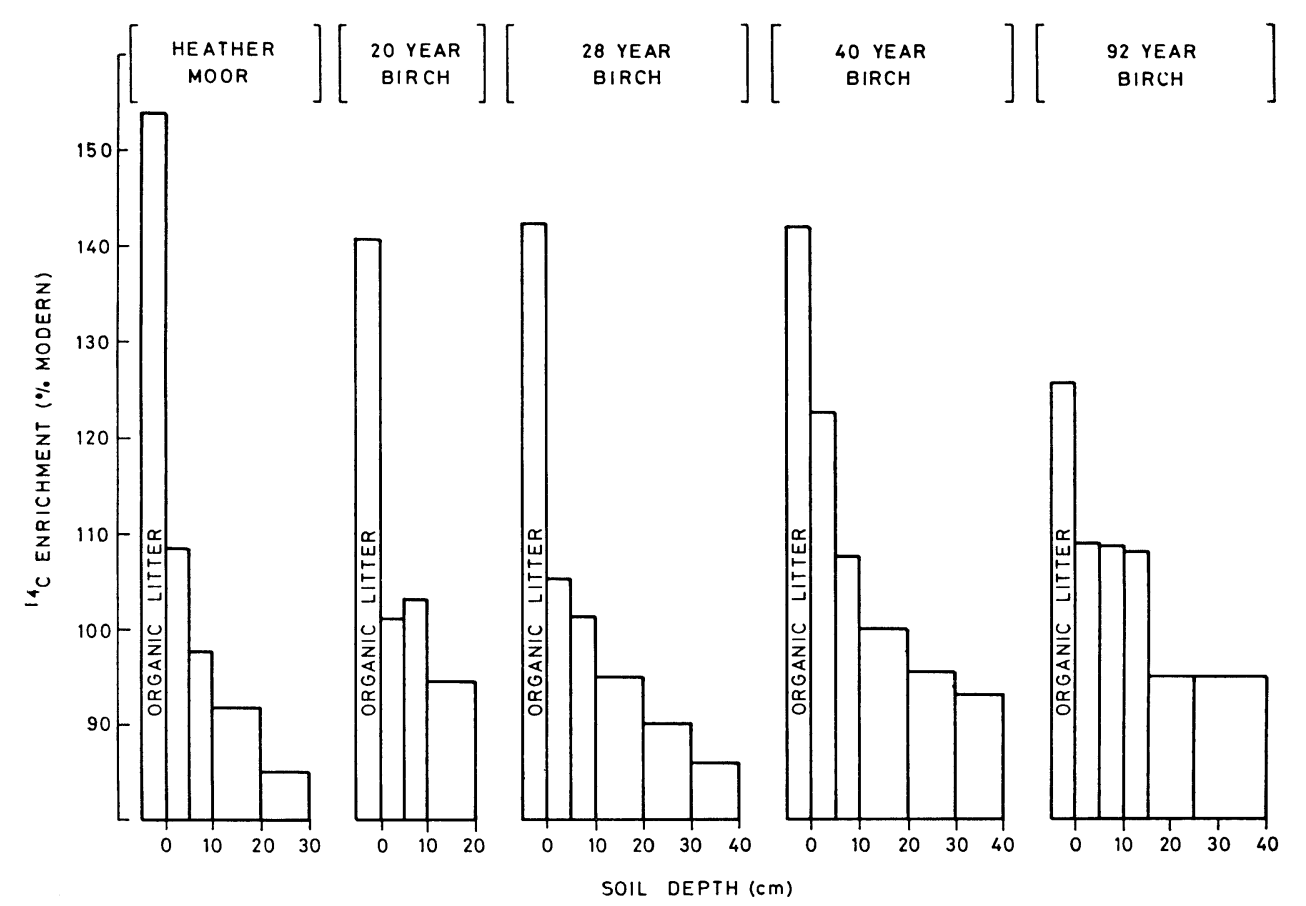

Fig 2. Measured ${ }^{14} \mathrm{C}$ enrichments. 
collected in a series of cryogenic traps and then purified by resublimation and pumping to a residual pressure of $10^{-4}$ torr at $-195^{\circ} \mathrm{C}$. The yield of $\mathrm{CO}_{2}$ was determined in a calibrated volume from which samples of gas were transferred to the mass spectrometer (VG Micromass 602B).

${ }^{13} \mathrm{C}$ enrichments were measured against a bulk $\mathrm{CO}_{2}$ working standard $\left(\delta^{13} \mathrm{C}=-27.8 \%\right.$ PDB $)$. The data presented in figure 3 are quoted relative to the PDB limestone standard. Overall analytical precision is estimated at better than \pm 0.2 percent (at the $2 \sigma$ confidence level) on the basis of sample replicates and a series of measurements on a bulk standard soil made at regular ( 5 sample) intervals throughout the duration of this investigation.

\section{INTERPRETATION AND DISCUSSION}

Isotopic comparisons are restricted to those values monitored for the total organic content of the mineral soils. No attempt was made to isolate component organic fractions since (1) the pedological significance of these extracts remains controversial (Scharpenseel and Schiffman, 1977) and (2) they were considered ill-defined and largely dependent on the particular chemical procedures used in their recovery (Goh and Molloy, 1978).

In the interpretation of measured ${ }^{14} \mathrm{C}$ enrichments, we have resisted the temptation to quantify these data in terms of a 'mean age' or 'residence time' for the soil carbon. Although, as pointed out by Jenkinson
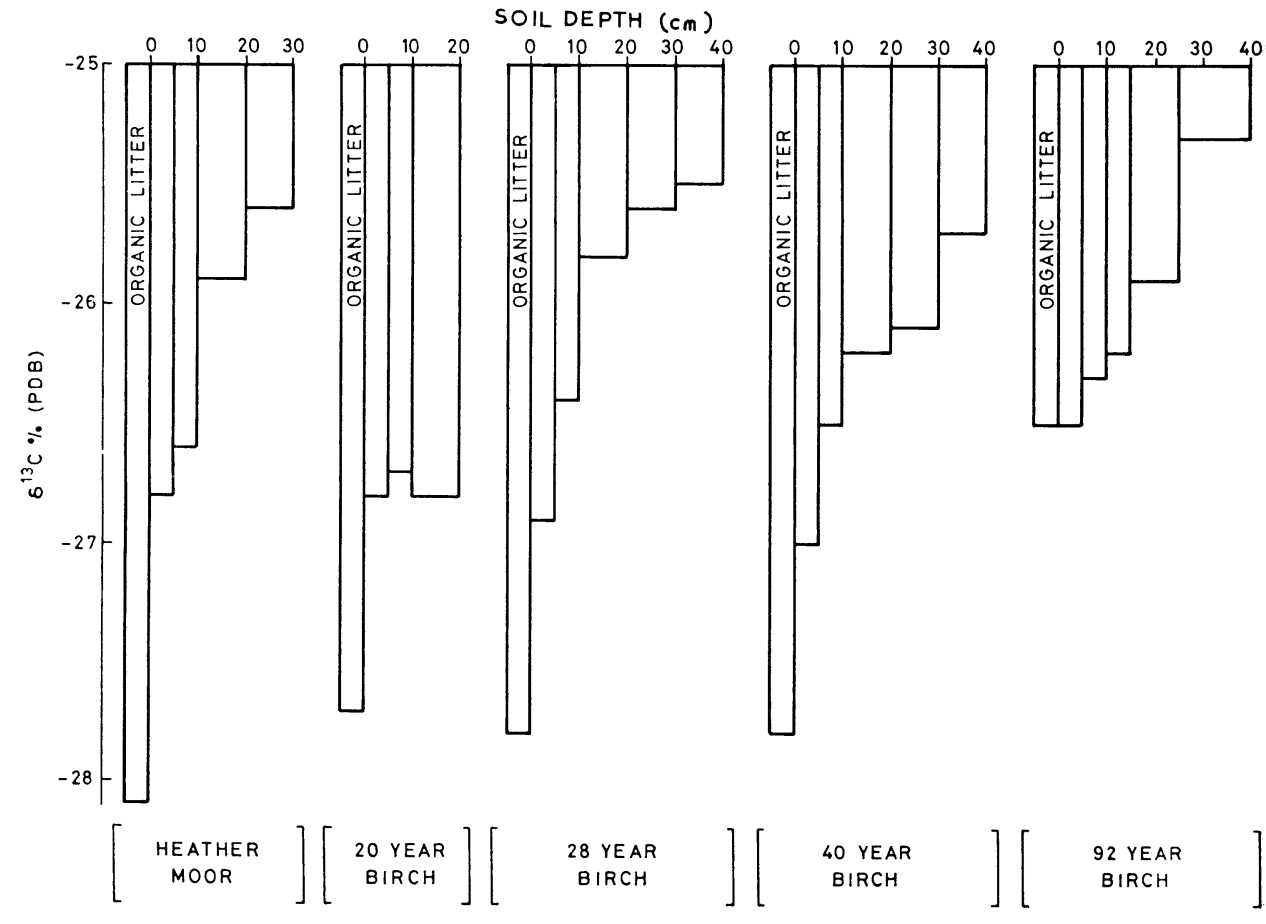

Fig 3. Measured ${ }^{13} \mathrm{C}$ enrichments. 
(1963), the ${ }^{14} \mathrm{C}$ enrichment in modern surface soils might be expected to be largely determined by the marked and, now, well-documented secular trend in atmospheric 'bomb' ${ }^{14} \mathrm{C}$ concentration, the influence of natural ${ }^{14} \mathrm{C}$ decay and/or industrial dilution (Suess effect) is clearly evident in all mineral horizons. Likewise, a dynamic modeling approach such as that proposed by Lobo and others (1974) has been avoided at this stage since, (1) with the possible exception of the parent moorland, these soils cannot be considered as being in a quasi steady state, and (2) as yet the data is insufficient to describe adequately the several mechanisms available for carbon input and mixing, $i e$, the incorporation of surface humus, root decay and exudation, faunal activity, etc.

Mechanisms which determine ${ }^{13} \mathrm{C}$ enrichment of soil carbon are also subject to some speculation (Stout, Rafter, and Troughton, 1975). It is our opinion that, in the present context, the isotopic differences noted for specific biochemical components in plant tissue (Smith, 1972) allied with their varying rate of decomposition is most significant. In this case, variations in $\delta^{13} \mathrm{C}$ are considered to reflect the stage of humification within a given depth profile or series of related soils. However, the influence of anthropogenically induced changes in the ${ }^{13} \mathrm{C} /{ }^{12} \mathrm{C}$ ratio of atmospheric $\mathrm{CO}_{2}$ during the past century (Stuiver, 1978) cannot be totally discounted.

A mathematical model approach capable of providing pedologically objective ${ }^{14} \mathrm{C}$ ages for surface soils is being considered. However, until this exercise is completed and reviewed we prefer to endorse the suggestion of Scharpenseel and Schiffman (1977), that the measured isotopic data be regarded more as inherent soil properties compatible with such characteristics as $\mathrm{pH}$, color, density, etc.

Inter-site comparison of the Tulchan soil series is most appropriate in terms of pedological horizons. The corresponding soil isotopic values, as calculated from the data in figures 1,2 , and 3 , are given in table 1 .

Litter horizons. Since the atmospheric ${ }^{14} \mathrm{C}$ concentration has been decreasing since 1964 , the pattern of ${ }^{14} \mathrm{C}$ enrichments indicates a more rapid turnover of organic litter under birch. This accords with the accumulation and relatively slow decomposition of mor humus at the moorland site. A more advanced state of humification at the birch sites is also supported by the similar, but inverted, pattern for ${ }^{13} \mathrm{C}$ enrichment. The enhancement of both ${ }^{14} \mathrm{C}$ and ${ }^{13} \mathrm{C}$ enrichment trends under the oldest (92-year) birch stands probably reflects the noted input of an appreciable amount of dead wood to the litter mass. This older material will have a much reduced or negligible 'bomb' ${ }^{14} \mathrm{C}$ concentration and a higher ${ }^{13} \mathrm{C}$ enrichment (ca-25\% PDB) compared with the bulk of dead organic material aggregated at the other sites.

$A$ horizons. The magnitude of the ${ }^{14} \mathrm{C}$ enrichment at all sites shows that, irrespective of soil changes, this horizon has retained a significant amount of carbon which is representative of 'pre-bomb' organic input. The change in ${ }^{14} \mathrm{C}$ enrichment at between 28 - and 40 -years birch growth probably reflects the effective transition from mor to mull humus. Input 
of older wood residues is again evident in the upper (A1) level at the oldest birch site. A faster turnover and/or deeper penetration of organic material is indicated after 40 years of birch growth. The occurrence of a comparatively low ${ }^{14} \mathrm{C}$ concentration at the 28-year birch site is also reflected in the underlying $\mathrm{A} / \mathrm{B}$ intergrade and could result from a net upward transport of carbon at this stage in the soil transformation. The lack of a significant variation in $\delta^{13} \mathrm{C}$ across the series is indicative of a constant state of organic decomposition and/or tissue differentiation. There may be a hint, from the $\delta^{13} \mathrm{C}$ value, of a slightly more humified contribution at the 28-year site.

Upper $B$ horizon. The ${ }^{14} \mathrm{C}$ enrichment pattern again reflects the transition to younger carbon after 40 years of tree growth although the possible transfer of 'post-bomb' input through the A/B intergrade cannot be resolved. As for the overlying horizons, $\delta^{13} \mathrm{C}$ values indicate a constancy in organic composition, but at a more advanced stage of decomposition or differentiation.

Miles (1977) has proposed that soil mixing is encouraged under birch by deeper root penetration and by the stimulation of soil fauna through an increase in soil $\mathrm{pH}$ and a reduction in the tannin content of the organic residues. As birch growth proceeds, there is a reduction in cation exchange capacity, an increase in microbal activity, and an acceleration in the rate of organic decomposition. The pattern of measured isotopic variations and its implied significance is in accordance with the interpretation from conventional soil analyses. A more comprehensive comparison of the data is underway.

TABLE 1

Comparison of carbon isotope distribution by pedological horizons

\begin{tabular}{|c|c|c|c|c|c|c|}
\hline & & $\begin{array}{l}\text { Heather } \\
\text { moor }\end{array}$ & $\begin{array}{c}\text { 20-year } \\
\text { birch }\end{array}$ & $\begin{array}{l}\text { 28-year } \\
\text { birch }\end{array}$ & $\begin{array}{l}\text { 40-year } \\
\text { birch }\end{array}$ & $\begin{array}{c}\text { 92-year } \\
\text { birch }\end{array}$ \\
\hline \multicolumn{7}{|l|}{ A1 horizon: } \\
\hline & Total carbon $\left(\mathrm{g} \mathrm{cm}^{-2}\right)$ & 0.48 & 0.14 & 0.39 & $0.48 *$ & 0.46 \\
\hline & ${ }^{14} \mathbf{C}(\%$ modern $)$ & 104.8 & 101.2 & 103.3 & $115.4 *$ & 108.6 \\
\hline \multirow[t]{4}{*}{ A1 + A2 horizon: } & $\delta^{13} \mathrm{C} \%$ (PDB) & -26.8 & -26.8 & -26.6 & $-26.8 *$ & -26.5 \\
\hline & Total carbon $\left(\mathrm{g} \mathrm{cm}^{-2}\right)$ & 0.74 & 0.27 & 0.70 & 0.88 & 0.69 \\
\hline & ${ }^{14} \mathrm{C}(\%$ modern $)$ & 102.1 & 102.3 & 99.6 & 108.6 & 108.3 \\
\hline & $\delta^{13} \mathrm{C} \% \circ(\mathrm{PDB})$ & -26.6 & -26.7 & -26.2 & -26.5 & -26.3 \\
\hline \multirow{3}{*}{$A / B$ intergrade: } & Total carbon $\left(\mathrm{g} \mathrm{cm}^{-2}\right)$ & - & 0.19 & 0.29 & 0.48 & 0.32 \\
\hline & ${ }^{14} \mathrm{C}$ (\% modern) & - & 94.5 & 90.0 & 95.5 & 95.0 \\
\hline & $\delta^{13} \mathrm{C} \%$ (PDB) & & -26.8 & -25.6 & -26.1 & -25.9 \\
\hline \multirow{3}{*}{$\begin{array}{l}\text { Be, upper } 10 \mathrm{~cm} \\
\text { of } \mathrm{B} \text { horizon }\end{array}$} & Total carbon $\left(\mathrm{g} \mathrm{cm}^{-2}\right)$ & 0.25 & - & 0.17 & 0.30 & 0.33 \\
\hline & ${ }^{14} \mathrm{C}$ (\% modern) & 85.4 & - & 86.2 & 93.1 & 95.4 \\
\hline & $\delta^{13} \mathrm{C} \%$ & -6 & & -25 & -25.7 & -25 \\
\hline \multirow{3}{*}{ Total soil to 1310 depth: } & Total carbon $\left(\mathrm{g} \mathrm{cm}^{-2}\right)$ & 0.99 & - & 1.16 & 1.66 & \\
\hline & ${ }^{14} \mathrm{C}(\%$ modern $)$ & 97.9 & - & 95.2 & 102.0 & 102.0 \\
\hline & $\delta^{13} \mathrm{C} \%$ (PDB) & -26.3 & - & -25.9 & -26.2 & -26.0 \\
\hline
\end{tabular}

* The Al horizon could not be readily discerned in this profile. A hypothetical boundary at $10 \mathrm{~cm}$ depth is used for comparison. 


\section{ACKNOWLEDGMENTS}

We thank J Miles, ITE, Banchory, for our introduction to his study sites and for access to and discussion of unpublished data. A T Harrison, ITE, Merlewood, arranged supporting analyses on our samples and has provided useful discussion in relation to this and allied studies. The overall financial support of the Natural Environment Research Council is gratefully acknowledged.

\section{REFERENCES}

Dimbleby, G W, 1951, The reversion of podsols to a brown forest soil under birch: Oxford, Imperial Forestry Inst Rept, 1945-50, p 7-8.

1952, Soil regeneration on the North-East Yorkshire moors: Jour Ecology, v 40, p 331-341.

North 1953, Natural regeneration of pine and birch on the heather moors of North-East Yorkshire: Forestry, v 24, no. 1, p 41-52.

Goh, K M and Molloy, B P J, 1978, Radiocarbon dating of paleosols using organic matter components: Jour Soil Sci, v 29, p 567-573.

Harkness, D D and Wilson, H W, 1972, Some applications in radiocarbon measurement at the Scottish Research Reactor Centre, in Rafter, T A and Grant-Taylor, T, eds, Internatl conf on radiocarbon dating, 8th, Proc: Wellington, Royal Soc New 7ealand, B102.

Jenkinson, D S, 1963, The turnover of organic matter in soil, in The use of isotopes in soil organic matter studies: FAE/IAEA tech mtg, Rept, Volkenrode, Pergamon Press, p 187-198.

Lobo, P F S, Flexor, J M, Rapaire, J L, and Sieffermann, G, 1974, Essai de determination du temps de residence des fractions humiques de deux sols ferrallitiques par l'utilisation du radiocarbone naturel et thermo-nucleaire: Cahiers ORSTROM, ser Podol, v 12, no. 1, p 115-123.

Miles, J, 1977, Effects of birch on heather moorland soils in northern Britain [abs]: British Ecol Soc Bull, v 7, no. 4, p 6.

Scharpenseel, H W and Schiffmann, H, 1977, Radiocarbon dating of soils, a review: Zeitschr Pflanzenernaehr Bodenkund, v 140, p 159-174.

Smith, B N, 1972, Natural abundance of the stable isotopes of carbon in biological systems: Bioscience, v 22, no. 4, p 226-231.

Stout, J D, Rafter, R A, and Troughton, J H, 1975, The possible significance of isotopic ratios in paleoecology: Royal Soc New Zealand Bull, v 13, p 279-286.

Stuiver, Minze, 1978, Atmospheric carbon dioxide and carbon reservoir changes: Science, v 199, p 253-258. 